\title{
Constructing public oral health policies in Brazil: issues for reflection*
}

\section{Catharina Leite Matos Soares}

Instituto de Saúde Coletiva, Univ Federal da Bahia - UFBA, Salvador, BA, Brazil.
* Paper presented at the "Oral Health Under an Integrality Perspective" International Symposium, held at the $17^{\text {th }}$ Congress of the Brazilian Association for Oral Health Promotion (ABOPREV), May 31 to June 2, 2012, Salvador, BA, Brazil.

Declaration of Interests: The author certifies that she has no commercial or associative interest that represents a conflict of interest in connection with the manuscript.

\section{Corresponding Author:}

Catharina Leite Matos Soares

E-mail:catharinamatos@gmail.com

Submitted: Sep 18, 2012

Accepted for publication: Oct 29, 2012

Last revision: Nov 26, 2012
Abstract: This paper addresses the construction of public oral health policies in Brazil by reviewing the available literature. It includes a discussion of the social responses given by the Brazilian State to oral health policies and the relationship of these responses with the ideological oral health movements that have developed globally, and that have specifically influenced oral health policies in Brazil. The influence of these movements has affected a series of hegemonic practices originating from both Market Dentistry and Preventive and Social Dentistry in Brazil. Among the state activities that have been set into motion, the following stand out: the drafting of a law to regulate the fluoridation of the public water supply, and the fluoridation of commercial toothpaste in Brazil; epidemiological surveys to analyze the status of the Brazilian population's oral health; the inclusion of oral health in the Family Health Strategy (Estratégia de Saúde da Familia - ESF); the drawing up of the National Oral Health Policy, Smiling Brazil (Brasil Sorridente). From the literature consulted, the progressive expansion of state intervention in oral health policies is observed. However, there remains a preponderance of hegemonic "dental" practices reproduced in the Unified Public Health Service (Sistema Único de Saúde - SUS) and the Family Health Strategy.

Descriptors: Oral Health; Health Policy; Dental Care.

\section{Introduction}

The literature contains different approaches to studying health policies. These involve an understanding of how a body such as the State responds to the health problems and needs of a population at different historical times, responses that are not necessarily of action, but may also be of omission, and illustrate the degree of commitment to specific social issues in the country. These approaches may also be understood as a set of intentions, principles and guidelines for a health issue that shapes the action plans and policies appearing in official documents. Moreover, they involve the distribution, relationships, struggles, nature and structure of power within the health sector. ${ }^{1}$

Viana's ${ }^{2}$ study in the field of dentistry was pioneering, in that it addressed oral health policies in Brazil from the perspective of state responses.

Other approaches deal with the policy cycle, which covers the phases in which a public policy is shaped, from the inclusion of an issue on an agenda, through the drawing up and implementation processes, to ulti- 
mate policy evaluation. ${ }^{3,4}$

A significant increase in scientific production regarding public oral health policies occurred simultaneously with the development of the Brazilian Health Reform (Reforma Sanitária Brasileira RSB), the establishment of the Unified Public Health Service (Sistema Único de Saúde - SUS), and the incorporation of oral health into this system. This can be evidenced by consulting the available databases, considering that approximately 1,000 titles were found in the databases we consulted. These studies address issues from decentralization to the incorporation of oral health into SUS, ${ }^{5}$ with a striking number of studies dealing with the incorporation of oral health into the Family Health Strategy (Estratégia de Saúde da Família - ESF). ${ }^{6-11}$

This phenomenon is not without reason, insofar as the incorporation of the Oral Health Team (Equipe de Saúde Bucal - ESB) into the Family Health Strategy aimed at reorganizing dental care through primary health care-that occupies a privileged place at the local level-supported by financial incentives available for this purpose, ${ }^{12}$ and strengthened by the drawing up of a specific policy in 2004 known as Smiling Brazil (Brasil Sorridente), ${ }^{13}$ which itself has been the target of studies at the local level. ${ }^{14}$

It is worth emphasizing that these policies are the product of an historical construction, and that the State and Brazilian society are structural components of this construction. This explains why these policies were established in one particular way and not another. In this sense, it is worthwhile to include some reflections that were made in a study on the Brazilian Health Reform regarding the State and Society in Brazil. The author reports that policies were drawn up and implemented by an authoritarian, bureaucratic and patrimonialist State, and a society witnessing a passive revolution, in which solutions generally came "from above," without the participation of the Brazilian people. However, like all dialectic processes, this one was textured by contradictions and specific historical moments, which gave rise to more progressive movements, like SUS, in which organized civil society played a central role. $^{15}$

These initial considerations must be borne in mind to understand both the relevance of the the oral health policy issue in Brazil and the foundations on which these policies are based, which is this article's subject of discussion. The article reviews the available literature to outline the main ideological movements in global oral health, which have influenced Brazil, and to relate them to Brazil's state responses to oral health throughout the $20^{\text {th }}$ and early $21^{\text {st }}$ centuries, highlighting the National Oral Health Policy (Política Nacional de Saúde Bucal PNSB), Smiling Brazil, drawn up in 2004.

\section{Discussion}

\section{Ideological movements in oral health: implications for oral health policies in Brazil}

The concepts of ideology and ideological movements are addressed by Arouca. ${ }^{16}$ Ideology encompasses both the system of ideas and representations that dominate the spirit of man or of a social group, and ideological practices, such as those activities carried out in order to transform any given ideology into another ideology. Thus, ideological movements are defined as a series of ideological practices, and an ideological movement represents a series of activities aimed at transforming one "global vision" into a new "global vision." There is a coherent body of ideas that have a dual function:

- on one hand, that of criticizing any ideology that seeks to replace itself, and,

- on the other, that of asserting the effectiveness of the solution to the issues presented, evidencing the emergence of new prospects that the prior movement was unable to fulfill.

Of the movements addressing ideas that have influenced the dental field, private dentistry-also known as market dentistry-is one that developed prominently in Brazil. Its expansion was promoted by the Brazilian capitalist state, which incorporated it into the public service system through social security. ${ }^{17}$

A systematic review of both the national and international literature reveals the dental sector's alignment with the interests of market dentistry. ${ }^{18}$ As a result, a series of hegemonic practices have developed 
in Brazil. Although they apply to private dentistry, they can also be found in the public sector.

From the 1950s onwards, a series of apparently contradictory movements began to coexist within the Brazilian context, among which the following stand out:

- Public Health Dentistry,

- Preventive Dentistry,

- Social Dentistry,

- Simplified Dentistry,

- Community Dentistry,

- Comprehensive Dentistry and

- Collective Dental Health.

To Narvai ${ }^{17}$ market dentistry has become hegemonic by aligning itself with the political and ideological interests of liberal society in Brazil, and all the descriptions that have emerged as counterhegemonic proposals have failed in their mission of breaking with this hegemony.

However, an analysis of the oral health care models in Brazil reveals the influence of these movements in incorporating oral health services in Brazil, whose practices have also become hegemonic in the dental field, even though they have taken on a subordinate position in relation to private or market dentistry, as can be observed in preventive and social dentistry. ${ }^{19}$

Public health dentistry developed in Brazil as of the 1950s, and is one of the forerunners of collective oral health practices. ${ }^{20}$ This movement was responsible for establishing the incremental system in health services, referring to the two phases of dental care:

- the preventive phase, with the introduction of fluoride mouthrinses and topical fluoride, and

- the curative phase, for children aged 6 to 14 years old within the school environment.

Another strategy of this system of ideas was the fluoridation of the public water supply, seen in the Aymorés pilot experience in Espírito Santo. ${ }^{17}$ In the 1980s, public health dentistry began to be called social dentistry, although it maintained the same theoretic assumptions. The progress witnessed in this movement in Brazil has been related to the in- troduction of programmed practice, although this is restricted to a specific population group.

Under the influence of the global preventive medicine movement that originated in American schools, preventive dentistry developed in a like manner, and its theoretical assumptions are founded on the natural history of disease (NHD) model, conceived by Leavell and Clark in 1975. The ideas contained in this movement gained ground in the dentistry field, through successful cariology studies conducted in Scandinavian countries, regarding the control of dental caries within these same countries. ${ }^{17} \mathrm{An}$ international overview of oral health, referred to by Portilho and Ferreira, ${ }^{21}$ provides evidence of the success of the global spread of the ideas of this movement in other countries. In Brazil, the foundation of the Brazilian Association for the Promotion of Oral Health (Associação Brasileira de Promoção da Saúde Bucal - ABOPREV) substantively supported the dissemination of these ideas. ${ }^{17}$

In Brazil, in the 1970s, under the influence of Latin America, the ideas propounded by the preventive dentistry movement, addressing simplified dentistry, gained ground. Their core elements were the standardization of professional practice and a reduction in surgical stages, by excluding that which is superfluous, simplifying and lowering prices. Although there was also talk of maintaining quality, program feasibility prescribed only the extending of coverage and the boosting of productivity. ${ }^{17}$ In the oral health policy sphere in Brazil, these ideas influenced the Program for the Internalization of Health Activities and Services (Programa de Interiorização das Ações e Serviços de Saúde - PIASS) and dentistry for workers, and were incorporated into the dental services of the Social Service of Commerce (Serviço Social do Comércio - SESC) and the Social Service of Industry (Serviço Social da Indústria SESI), through the establishment of modular clinics.

One outcome that deserves attention is that, as this area of knowledge became consolidated in Brazil, it was adopted at the state level, and incorporated into university curricula under the name of Preventive and Social Dentistry (Odontologia Preventiva e Social - OPS), which represents the merging of ideas contained in both movements. The in- 
fluence of Preventive and Social Dentistry on public oral health policies was significant in relation to three large-scale state activities:

a. the drafting of Law 6050, on May 24, 1974, which deals with the fluoridation of the public water supply; ${ }^{22}$

b. the fluoridation of commercial toothpaste in Brazil, and the inclusion of other preventive technologies, such as sealants and topical fluoride; and

c. the conducting of the first epidemiological survey to analyze the Brazilian population's oral health status, ${ }^{23}$ a survey that fueled discussions about oral health at the first Conference on Oral Health, two years later.

It can be seen that both Market Dentistry and Preventive and Social Dentistry have assumed hegemonic positions in Brazil. A review conducted by Narvai and Almeida ${ }^{24}$ reports on the growth in Preventive and Social Dentistry production, which had the second highest production in the prevention of oral diseases.

A proposition that strove to bridge this historical gap was placed on the agenda of the political movement for the democratization of the Brazilian society-the Health Reform and the establishment of SUS. The reform encompasses health promotion, the prevention of oral diseases and dental care.

An analysis of the oral health policies in the 20 years of SUS reveals that the advances observed in relation to oral health in Brazil are: 1) the creation of a dental department within the National Institute of Medical Welfare and Social Security (Instituto Nacional de Assistência Médica da Previdência Social - INAMPS), a body under the existing at the time Ministry of Social Security, and 2) the implementation of the National Policy to Control Dental Caries (Programa Nacional de Controle da Cárie Dental - PNCCSF), both of which were centralizing measures. Simultaneously, the Ministry of Health launched the National Oral Health Policy through the National Program for the Prevention of Dental Caries (Programa Nacional de Prevenção da Cárie Dental - PRECAD), even though this countered the effort of decentralization. Moreover, during the Collor government, oral health targets were established in the five-year oral health plan of 1990-1995, and the National Division of Oral Health was turned into a Technical Department under the National Department of Health Care. A ruling was then approved, which incorporated collective procedures (CP) into oral health. Oral health was incorporated into Family Health, and the National Oral Health Policy, Smiling Brazil was drafted..$^{25}$

Some authors associate the incorporation of dentistry into SUS with the ideas of the Collective Oral Health (Saúde Bucal Coletiva - SBC) movement. ${ }^{17}$ In the literature, this movement, initiated in the 1980s, represents a range of concepts, but Collective Oral Health is understood here as a theoretical and political movement of national origin, whose scientific frame of reference is not related to social stratification. It refers to all the processes of social, biological and psychological nature, and is understood as a movement consistent with Collective Health, whose historical commitment is to the quality of life in society and the defense of citizenship. ${ }^{26}$ From this perspective, Collective Oral Health maintains a dialogue with both Brazilian Health Reform and SUS. Its assumptions influenced the debates of the third National Conference on Oral Health ${ }^{27}$ and the drafting of the National Oral Health Policy, Smiling Brazil. ${ }^{13}$ Table 1 summarizes the main ideological movements that have influenced Brazil and the Brazilian State's respective oral health social responses.

\section{Oral health policies in the $21^{\text {st }}$ century: from the inclusion of oral health in the Family Health Strategy to the National Oral Health Policy}

At the start of the $21^{\text {st }}$ century, the Family Health Program (later developing into the Family Health Strategy) was adopted as a strategy to reorganize Brazil's health care model, and progressed substantively. An analysis of its implementation indicates numerical expansion, extended health care coverage and the incorporation of new professional practices into primary care. ${ }^{28}$ This progress may have driven the Oral Health Team to be incorporated into the Family Health Strategy. ${ }^{12}$

The heterogeneity and complexity of the process that established the Oral Health Team in the Family 
Table 1 - The main influential ideological movements and oral health policies in Brazil.

\begin{tabular}{|c|c|c|}
\hline Movement & Core ideas & State responses in Brazil \\
\hline Public / Social Dental Health & $\begin{array}{l}\text { This corresponds to public health and addresses the } \\
\text { oral health of the community; it strives to resolve } \\
\text { community health issues in practice }\left(\mathrm{Chaves}^{20}\right) \text {. The } \\
\text { movement's frame of reference is North American } \\
\left.\text { public health (Narvai }{ }^{77}\right) \text {. It developed in Brazil in the } \\
1950 \text { s. As of the following decade, the movement } \\
\text { transmuted into the so-called social dentistry } \\
\text { movement. }\end{array}$ & $\begin{array}{l}\text { An incremental system to provide care to groups of } \\
\text { schoolchildren aged between } 6 \text { and } 14 \text { years old, } \\
\text { and fluoridation of the public water supply (pilot } \\
\text { experience in Baixo Gandu, state of Espírito Santo). } \\
\text { Its operations came under the responsibility of the } \\
\text { Special Public Health Services (Serviços Especiais de } \\
\text { Saúde Pública - SESP), which later became the SESP } \\
\text { Foundation. }\end{array}$ \\
\hline Preventive Dentistry & $\begin{array}{l}\text { It developed in Brazil as of the 1970s. It gained } \\
\text { ground in Scandinavian countries following cariology } \\
\text { studies; ABOPREV was the main disseminator } \\
\text { of these ideas, striving to prevent oral diseases, } \\
\text { particularly caries. It sought to embrace an ecological } \\
\text { or multifactorial concept of disease, classified as } \\
\text { NHD (Natural History of Disease), and proposed } \\
\text { interventions in the disease chain. }\end{array}$ & $\begin{array}{l}\text { The incorporation of fluorides into the dental caries } \\
\text { prevention system was enacted by Law 6050, which } \\
\text { made both the fluoridation of the public water supply } \\
\text { and the inclusion of fluoride in commercial toothpaste } \\
\text { mandatory in Brazil. Preventive Dentistry was } \\
\text { responsible for introducing a wide range of fluoride- } \\
\text { related technologies, such as toothpastes, fluoride } \\
\text { gels and sealants. }\end{array}$ \\
\hline Simplified Dentistry & $\begin{array}{l}\text { A movement focusing on the health team, imposing } \\
\text { the practice of delivering dental care with rationality, } \\
\text { and emphasizing curative care. To this end, it utilizes } \\
\text { changes in the architecture of physical space. It } \\
\text { represents standardized professional practice, a } \\
\text { reduction in surgical stages, and the elimination of } \\
\text { what is superfluous, making dentistry simpler and } \\
\text { cheaper to enable greater productivity. }\end{array}$ & $\begin{array}{l}\text { Adapting dental practices to incorporate auxiliary } \\
\text { personnel. Programs to extend coverage. }\end{array}$ \\
\hline Collective Oral Health & $\begin{array}{l}\text { A Brazilian theoretical and political movement. It } \\
\text { refers to all the processes of social, biological and } \\
\text { psychological nature and is a movement linked to } \\
\text { collective health. }\end{array}$ & $\begin{array}{l}\text { Inclusion of dentistry in the Unified Public Health } \\
\text { System through a range of Basic Operating } \\
\text { Standards. Incorporation of dentistry into the Family } \\
\text { Health Strategy. Formulation of the National Oral } \\
\text { Health Policy. }\end{array}$ \\
\hline
\end{tabular}

Health Strategy are reflected in the context of local government. However, common issues have posed difficulties in setting up Oral Health Teams in the Family Health Strategy. These include:

- reproducing traditional practices-both clinical and collective;

- weak links and poor working conditions, reflected in the degree of professional commitment; and

- the difficulty of inserting planning and management technology into the health team's daily work life. ${ }^{6,8-11,29}$

If an Oral Health Team were established in the Family Health Strategy, first, it would form critical knots that would entangle the structural issues of the Brazilian State. Secondly, the team represents an arena for experimenting innovative practices and proposing changes to the health care model. ${ }^{28}$ This is why it was incorporated as a strategic line within the National Oral Health Policy. ${ }^{13}$

The National Oral Health Policy covers the organization of oral health care at all levels of care. Its principal guidelines prioritize the following lines of action:

a. the incorporation of oral health into the family health strategy, in order to reorganize primary care;

b. the qualification of oral health professionals, auxiliaries, technicians and dentists, through ongoing education;

c. the inclusion of complex procedures in basic care;

d. the reorganization of specialized care, with the establishment of Dental Specialty Centers (Centros de Especialidade Odontológica - CEO) and Prosthodontic Laboratories (Laboratórios de Prótese Dentária - LPD);

e. the providing of hospital care, by reorganizing emergency dental services and including oral health in hospital care; 
f. the organization of oral health services along epidemiological principles;

g. the definition of policy criteria to guarantee access to oral health services according to lines of care or living conditions; and

h. enabling greater access of the population to fluoridated water by fluoridation of the public water supply. ${ }^{13}$

In view of its reorganizing potential, the formulation of the National Oral Health Policy represents progress in implementing oral health policies. However, in the years to come a critical analysis of this formulation may result in the redesigning of the pathways of progress. This is borne out by the significant increase in the number of Oral Health Teams in the Family Health Strategy, i.e., by April 2012 , it had risen to 4,880 teams. This increase is attributed to the financial incentive mechanisms used by the Ministry of Health to implement and fund the teams. ${ }^{12}$ It is worth remembering that quantitative expansion does not mean that the practices of agents in the Family Health Program have changed, although it does represent a potential for improved practices.

A recent study sought to determine whether the incorporation of Oral Health Teams into the Family Health Strategy has had an impact on oral health indicators related to the prevalence of injuries and their respective treatment coverage, to access to public services, and to preventive oral health actions. The study used the Northeastern population residing in municipalities with a population over 100,000 inhabitants as a reference, and concluded that performance of these teams in the municipalities studied was poor. ${ }^{30}$ Pimentel et al. ${ }^{31}$ analyzed the work processes of oral health teams in the state of Pernambuco and confirmed the following points:

- the existence of educational practices targeting specific groups in the health units, but also targeting schools in the communities;

- the organization of services not aligned with epidemiological criteria, insofar as diagnosis was made only as of last year; and

- the providing of care based on spontaneous demand.
These findings indicate that oral health practices are persistently based on hegemonic models, and that it is difficult to break with these practices in order to organize an oral health care system in line with with SUS and the National Oral Health Policy, and with the ideological and political concepts that apply to Collective Oral Health.

According to Narvai, ${ }^{32}$ the significant progress made in developing this policy can be attributed to the institutionalization of the epidemiological survey. This had led to promoting the organization of activities under epidemiological criteria and to defining the allocation of funds. Another progress-driving measure includes the expansion of fluoridation of the public water supply, due to its intersectoral importance and to the greater number of municipalities with access to fluoridated water.

The quantitative expansion of specialized care represents the apex of the National Oral Health Policy, ${ }^{32}$ although the literature provides evidence of difficulties in accessing this level of care. ${ }^{14,33}$ Studies reveal that compliance with criteria and standards facilitates the widespread implementation of Dental Specialty Centers. ${ }^{33}$ Another analysis demonstrates that neglecting theoretical assumptions may compromise the organization of care in general. ${ }^{32}$

The study conducted by Goes et al. ${ }^{34}$ analyzed 613 Dental Specialty Centers, mostly established in municipalities of medium-level care reference, and showed secondary care compliance in municipalities with less than $50 \%$ coverage. However, this finding may suggest an increase in spontaneous demand and a lack of coordination with primary care, since low primary care coverage compromises the referencing process, hence, the importance of questioning the implementation of Dental Specialty Centers in municipalities where basic care is not provided at a minimum of $50 \%$ coverage.

A critical point for implementing the National Oral Health Policy lies within the context of its practice. Despite efforts in establishing policy guidelines for constructing comprehensive oral health care, market dentistry as well as preventive and social dentistry remain hegemonic. They strengthen the concept of individual clinical care and prevention of oral diseases in specific groups, particularly 
schools. ${ }^{6,10}$ The use of technology applied to planning, management, and health-related social sciences, has not been addressed.

It seems that social participation and oversight are factors that have not been included. The last National Conference on Oral Health took place in 2004, served as the foundation for preparing the National Oral Health Policy, and has required specific attention. ${ }^{32}$

It can be said that oral health has progressively earned its place on the public health policy scene, with the progressive expansion of state interventions. Analyzing this through the literature brings into evidence the importance that this topic acquired at the beginning of the $21^{\text {st }}$ century, particularly with the incorporation of Oral Health Teams into the Family Health Strategy, which expanded with the addition of the National Oral Health Policy, Smiling Brazil, and was reconfirmed by the attention it received in the restructured primary care policy of 2011. ${ }^{35}$ The studies of Machado et al. ${ }^{36}$ and Paim et al. ${ }^{37}$ corroborate this assertion, insofar as both studies confirmed the inclusion of oral health when they respectively analyzed the government's agenda priorities and the health system in Brazil at the beginning of the $21^{\text {st }}$ century.

\section{Final Considerations}

An analysis of oral health policies in Brazil shows significant progress in respect to the participation of the State and to the constitution of a normative policy framework, expressed in the National Oral Health Policy and the ordinances that guarantee its implementation. Challenges include the implementation process, which requires the participation of local governments.

The National Oral Health Policy offers guidelines for reorganizing oral health care at all levels of care; however it mistakenly privileges some directives, such as the establishment of Dental Special-

\section{References}

1. Paim JS, Teixeira CF. Política, planejamento e gestão: balanço do estado da arte. Rev Saude Publica. 2006 Aug;40(Spec no):73-8. ty Centers, which may be the locus of primary care and may favor the maintenance of a model centered on spontaneous demand and market dentistry.

Despite the institutional potential of the Family Health Strategy, the literature demonstrates the persistent reproduction of practices derived from the two hegemonic oral health models, i.e., market dentistry and preventive and social dentistry. It is important that the Family Health Strategy break with these models in order to shape a theoretical frame of reference to drive a new intellectual, moral and cultural course $^{38}$ for dental pratices.

This new direction should be more consistent with the democratic assumptions of SUS ${ }^{39}$ and Collective Oral Health ideas that can lead to rupture from the reproduction of policies for care practices that favor SUS for the poor, ${ }^{39}$ taking into consideration the contradictions inherent in society.

It has been suggested that Collective Oral Health has the potential to do this, but it may be necessary to root a movement of this nature in epistemological soil that can sustain its practice. After all, what is Collective Oral Health practice?

The literature consulted indicates the potential of the National Oral Health Policy to reorganize oral health consistent with the principles and guidelines of both SUS and the Brazilian Health Reform. However, this not only involves the political will of agents who have addressed the construction of a policy as a whole, but also signals the need to bring about changes in society and the State. Nonetheless, these changes do not seem to capture the attention of the Brazilian population, since they are constructed on structural issues. The literature also indicates the need to create institutional participatory mechanisms, which can establish a dialogue with SUS's participation structures within the sphere of civil society, whose involvement has been paramount at specific historical moments, such as those of Brazilian Health Reform and SUS construction.

2. Vianna MIP. Emergência das políticas de saúde bucal no Brasil: uma análise do período de 1923-1973. Rev Fac Odontol Univ Fed Bahia. 1988 Dec-1989 Jan;(8-9):28-49. 
3. Pinto ICM. Construção da agenda governamental: atores, arenas e processo decisório na saúde. Revista O\&S UFBa [Internet]. 2008 Jan-Dec [cited 2012 Nov 07];15(44):13-23. Available from: http://www.revistaoes.ufba.br/viewarticle. php?id= 343 .

4. Pinto ICM, Teixeira CF. Formulação da Política de Gestão do Trabalho e Educação da Saúde: o caso da Secretaria Estadual de Saúde da Bahia, Brasil, 2007-2008. Cad Saude Publica. 2011 Sep;27(9):1777-88.

5. Chaves SCL, Vieira-da-Silva LM. Atenção à saúde bucal e a descentralização da saúde no Brasil: estudo de dois casos exemplares no Estado da Bahia. Cad Saude Publica. 2007 May;23(5):1119-31.

6. Pereira DQ, Pereira JCM, Assis MMA. A prática odontológica em unidades. básicas de saúde em Feira de Santana (BA) no processo de municipalização da saúde: individual, curativa, autônoma e tecnicista. Cien Saude Colet. 2003;8(2):599-609.

7. Farias MAV, Moura ERF. Saúde Bucal no Contexto do Programa Saúde da Família do Município de Iracema, no Ceará. Rev Odontol UNESP. 2003 Jul-Dec;32(2):131-7.

8. Oliveira JLC, Saliba NA. Atenção Odontológica no Programa de Saúde da Família de Campos dos Goytacazes. Cien Saude Colet. 2005 Sep-Dec;10(suppl):297-302.

9. Baldani MH, Fadel CB, Possamai T, Queiroz MGS. A inclusão da odontologia no Programa de Saúde da Família no Estado do Paraná, Brasil. Cad Saude Publica. 2005 JulAug;21(4):1026-35.

10. Souza TMS, Roncalli AG. Saúde Bucal no Programa de Saúde da Família: uma avaliação do modelo assistencial. Cad Saude Publica. 2007 Nov;23(11):2727-39.

11. Lourenço EC, Silva ACB, Meneghin MC, Pereira AC. A inserção de equipes de saúde bucal na saúde da família no Estado de Minas Gerais. Cien Saude Colet. 2009 Oct;14(suppl 1):136777.

12. Brasil. Portaria n.1144, 28 dezembro 2000. Estabele incentivos financeiros para a reorganização da atenção à saúde bucal prestada nos municípios por meio do Programa de Saúde da Família. Diário Oficial da República Federativa do Brasil, Poder Executivo, Brasília (DF): 2000 dez. 28;Sec.1:85 [citado 19 jul. 2012]. Disponível em: http://www.mp.go.gov.br/portalweb/hp/2/docs/portaria1444_28_12_00.pdfBrasil.

13. Brasil. Ministério da Saúde. Diretrizes da Política Nacional de Saúde Bucal. Coordenação Nacional de Saúde Bucal; 2004. [citado 10 jul. 2012]. Disponível: http://bvsms.saude.gov.br/ bvs/publicacoes/politica_nacional_brasil_sorridente.pdf.

14. Soares CLM, Paim JS. Aspectos críticos para implementação da politica de saúde bucal no município de Salvador, Bahia, Brasil. Cad Saude Publica. 2011 May;27(5):966-974.

15. Paim JS. Reforma Sanitária Brasileira: contribuição para a compreensão e crítica. Salvador: Edufba; 2008. 356 p. Copublished by Unesp.
16. Arouca S. O dilema preventivista: contribuição para a compreensão e crítica da medicina preventiva. Rio de Janeiro: Fiocruz; 2007. 272 p. Co-published by Unesp.

17. Narvai PC. Saúde bucal coletiva: caminhos da odontologia sanitária à bucalidade. Rev Saude Publica. 2006 Aug;40(no spec):141-7.

18. Dias AA, Narvai PC, Rego DM. Tendências da produção científica em odontologia no Brasil. Rev Panam Salud Publica. $2008 \mathrm{Jul} ; 24(1): 54-60$.

19. Nickel DA, Lima FG, Silva BB. Modelos assistenciais em saúde bucal no Brasil. Cad Saude Publica. 2008 Fev;24(2):241-5.

20. Chaves MM. Odontologia social. Rio de Janeiro: Artes Médicas; 1986.448 p.

21. Portilho JAC, Ferreira LB. Sobre os avanços da Política Nacional de Saúde Bucal. Rev Tempus. 2011;5(3):35-47.

22. Brasil. Lei n. 6050 de 27 de maio de 1974. Dispõe sobre a fluoretação da água em sistemas de abastecimento quando existir estação de tratamento. Diário Oficial da União, Brasília (1974 maio 27); Sec.1:6021 [citado 19 jul. 2012]. Disponível em: planalto.gov.br/ccivil_03/LEIS/L6050.htm.

23. Brasil. Ministério da Saúde. Divisão Nacional de Saúde Bucal. Levantamento epidemiológico em saúde bucal. Brasília (DF): Ministério da Saúde; 1986.137 p. (Série C: Estudos e Projetos, 4). [citado em 19 jul. 2012]. Disponível em: http://dtr2004. saude.gov.br/dab/saudebucal/vigilancia.php.

24. Narvai PC, Almeida ES. O sistema de saúde e as políticas de saúde na produção científica odontológica brasileira no período 1986-1993. Cad Saude Publica. 1998;14(3):513-21

25. Frazão P, Capel PC. Saúde Bucal no Sistema Único de Saúde: 20 anos de luta por uma política pública. Saúde Debate Saude Debate. 2009 Jan-Apr;33(81):64-71.

26. Frazão P, Narvai PC. Saúde bucal no Brasil: muito além do céu da boca. Rio de Janeiro: Fiocruz; 2008. 147 p.

27. Brasil. Ministério da Saúde (MS). Conselho Nacional de Saúde. Relatório Final da $3^{\mathrm{a}}$ Conferencia Nacional de Saúde Bucal. 2005. 148 p. [citado em 23 jul. 2012]. Disponível em: http://conselho.saude.gov.br/biblioteca/Relatorios/saude_bucal.pdf.

28. Escorel S, Giovanella L, Mendonça MMH, Senna MCM. O Programa de Saúde da Família e a construção de um novo modelo para a atenção básica no Brasil. Rev Panam Salud Publica. 2007 Mar;21(2-3):164-76.

29. Nascimento AC, Moysés ST, Bisinelli JC, Moysés SJ. Saúde bucal na estratégia de saúde da família: mudança de práticas ou diversionismo. Rev Saude Publica 2009 MayJun;43(3):455-62.

30. Pereira CRS, Roncalli AG, Cangussu MCT, Noro LRA, Patrício AAR, Lima KC. Impacto da Estratégia Saúde da Família sobre indicadores de saúde bucal: análise em municípios do Nordeste brasileiro com mais de 100 mil habitantes. Cad Saude Publica. 2012 Mar;28(3):449-62. 
31. Pimentel FC, Albuquerque PC, Martelli PJL, Souza WV, Accioli RML. Caracterização do processo de trabalho das equipes de saúde bucal em municípios de Pernambuco, Brasil, segundo porte populacional: da articulação comunitária à organização do atendimento clínico. Cad Saúde Pública. 2012 Mar;28 Suppl:s146-57.

32. Narvai PC. Avanços e desafios da Política Nacional de Saúde Bucal no Brasil. Rev Tempus. 2011;5(3):21-34.

33. Figueiredo N, Goes PSA. Contribuição da atenção secundária em saúde bucal: um estudo sobre os centros de especialidade odontológica em Pernambuco, Brasil. Cad Saude Publica. 2009 Fev;25(2):259-67.

34. Goes PSA, Figueredo N, Neves JC, Silveira FMM, Costa JFR, Pucca Júnior GA, et al. Avaliação da atenção secundária em saúde bucal: uma investigação nos centros de especialidades do Brasil. Cad. Saude Publica. 2012;28 Suppl:s81-9.

35. Brasil. Ministério da Saúde. Portaria 2488/GM, 21 de outubro de 2011. Aprova a Política Nacional de Atenção Básica, estab- elecendo a revisão de diretrizes e normas para a organização da Atenção Básica, para a Estratégia Saúde da Família (ESF) e o Programa de Agentes Comunitários de Saúde (PACS). Diário Oficial da União. 2011. 24 out. [citado em 16 out. 2012]. Disponível em http://189.28.128.100/dab/docs/legislacao/portaria2488_21_10_11.pdf.

36. Machado CV, Baptista TWF, Nogueira CO. Políticas de saúde no Brasil nos anos 2000: a agenda federal de prioridades. Cad Saude Publica. 2011 Mar;27(3):521-32.

37. Paim JS, Travassos C, Almeida C, Bahia L, Macinko J. The Brazilian health system: history, advances, and challenges. Lancet. 2011 May;377(9779):1778-97.

38. Gramsci A. Cadernos do cárcere. Rio de Janeiro: Civilização Brasileira; 2000. v.3.

39. Paim JS. O que é o SUS. Rio de Janeiro: Fiocruz; 2009.144 p. 